\title{
Correction
}

\section{Correction to: Metformin activates chaperone-mediated autophagy and improves disease pathologies in an Alzheimer disease mouse model}

\author{
Xiaoyan $\mathrm{Xu}^{1,2}$, Yaqin Sun ${ }^{1}$, Xufeng Cen ${ }^{1}$, Bing Shan ${ }^{4}$, Qingwei Zhao ${ }^{1}$, Tingxue Xie ${ }^{1}$, Zhe Wang ${ }^{5}$, \\ Tingjun $\mathrm{Hou}^{5}$, Yu Xue ${ }^{6}$, Mengmeng Zhang ${ }^{4}$, Di Peng ${ }^{6}$, Qiming Sun ${ }^{1}$, Cong Yi ${ }^{1}$, Ayaz Najafov ${ }^{3 凶}$, \\ Hongguang $\mathrm{Xia}^{1,2 \bowtie}$ \\ ${ }^{1}$ Department of Biochemistry \& Research Center of Clinical Pharmacy of The First Affiliated Hospital, Zhejiang University \\ School of Medicine, Hangzhou 310058, China \\ 2 Liangzhu Laboratory, Zhejiang University Medical Center, Hangzhou 311121, China \\ ${ }^{3}$ Department of Cell Biology, Harvard Medical School, Boston, MA 02115, USA \\ ${ }^{4}$ Interdisciplinary Research Center on Biology and Chemistry, Shanghai Institute of Organic Chemistry, Chinese Academy of \\ Sciences, Shanghai 201203, China \\ ${ }^{5}$ College of Pharmaceutical Sciences, Hangzhou Institute of innovative Medicine, Zhejiang University, Hangzhou 310058, \\ China \\ ${ }^{6}$ Key Laboratory of Molecular Biophysics of Ministry of Education, Hubei Bioinformatics and Molecular Imaging Key \\ Laboratory, College of Life Science and Technology, Huazhong University of Science and Technology, Wuhan 430074, China \\ 凶Correspondence: najafov@gmail.com, ayaz_najafov@hms.harvard.edu (A. Najafov), hongguangxia@zju.edu.cn (H. Xia)
}

\section{CORRECTION TO: PROTEIN CELL}

HTTPS://DOI.ORG/10.1007/S13238-021-00858-3

In legend of figure 1 , this sentence "(C) 293THK cells were treated as in a" should be corrected as "(C) 293THK cells were treated as in (A)".

In legend of figure 2, "E-64D (10 $\mu \mathrm{mol} / \mathrm{L})$ " in description of panel (B) should be removed.

In section "Metformin activates chaperone-mediated autophagy" of RESULTS, E-64D in sentence "Metformin- induced degradation of HK2 and PKM2 was blocked by lysosomal inhibitors (E-64D, Bafilomycin A1 and Leupeptin + $\mathrm{NH}_{4} \mathrm{Cl}$ )" should be removed.

The word "upon" in the sentence "Moreover, the activation of astrocytes in the hippocampus, as judged by GFAP staining, was also reduced upon following Metformin treatment (Fig. 6C)" should be removed.

The correct Fig. 2 is shown below.
Xiaoyan Xu, Yaqin Sun, Xufeng Cen, Bing Shan have contributed equally to this work.

The original article can be found online at https://doi.org/10.1007/ s13238-021-00858-3. 
A

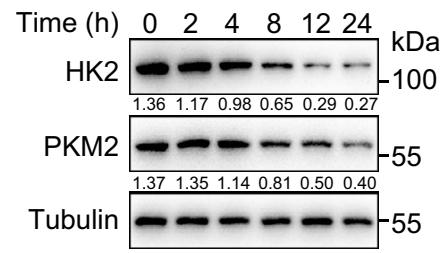

D

Metformin - + - + +

si-Control ++---

si-Lamp2a \#1 - - + + -

si-Lamp2a \#2 $-\quad-\quad+\quad+k \mathrm{kDa}$ Lamp2a $\underset{1.671 .670 .480 .260 .280 .36}{-100}$

0
0
0
5
0
0
0
0

G

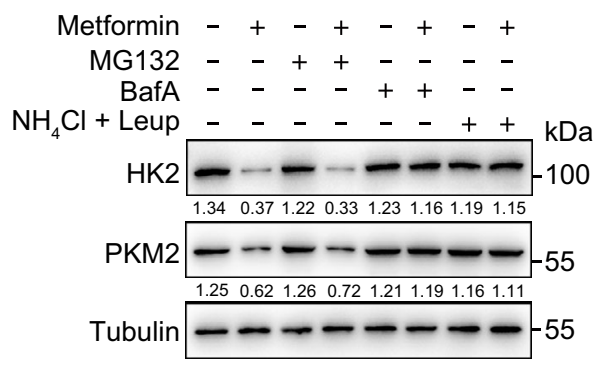

E

$$
\begin{aligned}
& \text { Metformin - - + } \\
& \text { Hsc70-Flag }-++\mathrm{kDa}
\end{aligned}
$$

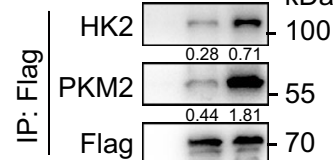

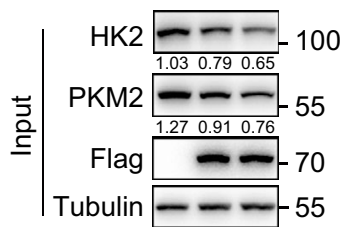

C Metformin -+-+-+

si-Control ++---

si-Hsc70 \#1 - -++-

si-Hsc70 \#2 - $-\quad-++\mathrm{kDa}$

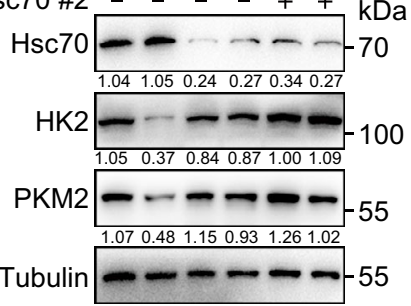

F

Metformin - - +

Lamp2a-Flag $-++\mathrm{kDa}$

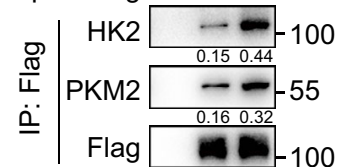

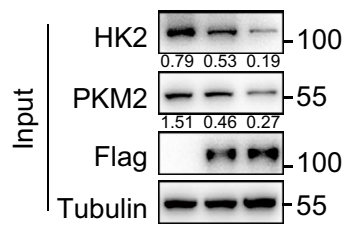

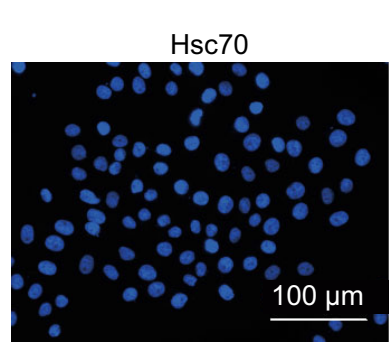
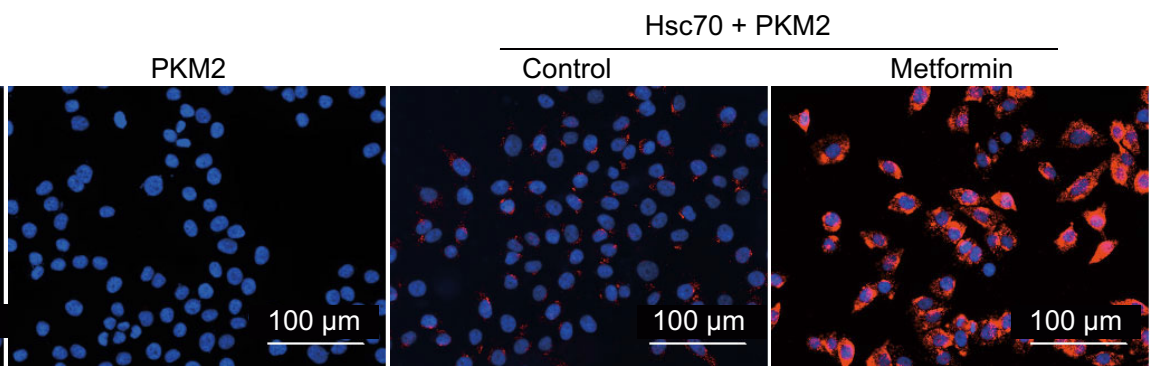

।

Lamp2a

PKM2
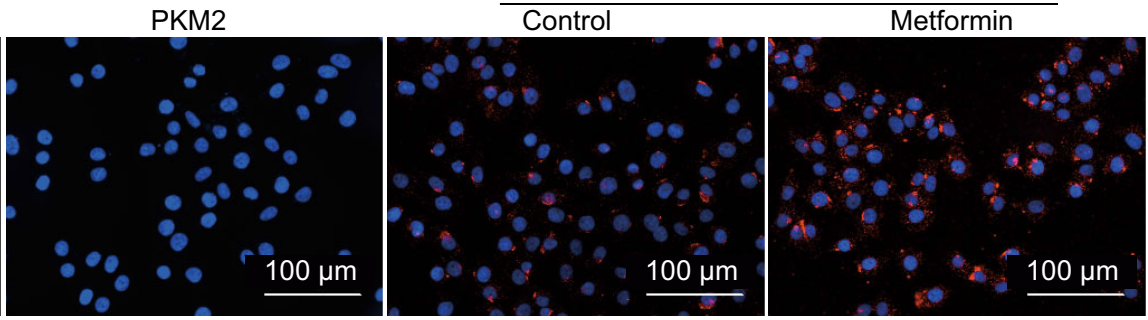

$\mathrm{H}$
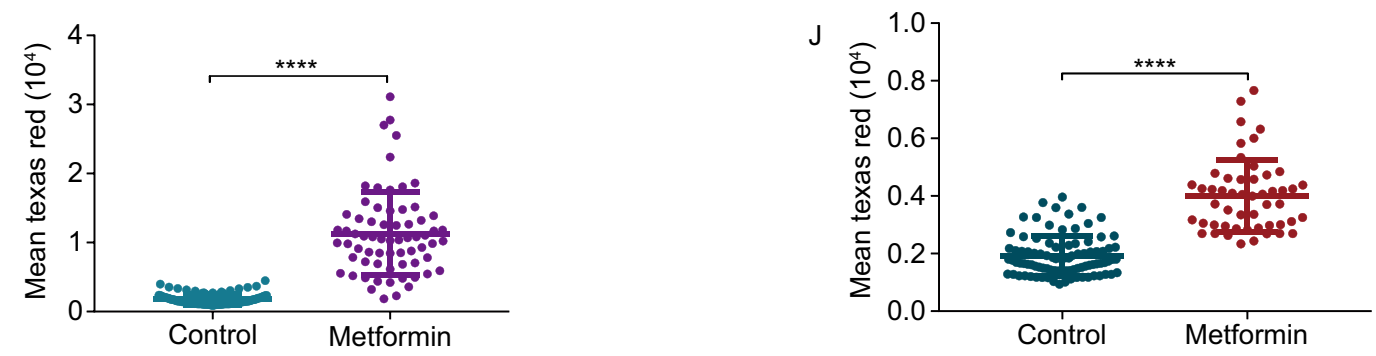
Figure 2. Metformin activates chaperone-mediated autophagy. (A) $\mathrm{H} 4$ cells were treated with $20 \mathrm{mmol} / \mathrm{L}$ Metformin for 2, 4, 8, 12, and $24 \mathrm{~h}$. Cell lysates were immunoblotted with indicated antibodies. (B) $\mathrm{H} 4$ cells were treated with $20 \mathrm{mmol} / \mathrm{L}$ Metformin with or without MG132 (10 $\mu \mathrm{mol} / \mathrm{L})$, Bafilomycin A1 (100 nmol/L), $\mathrm{NH}_{4} \mathrm{Cl}$ $(20 \mathrm{mmol} / \mathrm{L})$, Leupeptin $(100 \mathrm{nmol} / \mathrm{L})$, for $12 \mathrm{~h}$. Cell lysates were immunoblotted with indicated antibodies. (C and D) H4 cells were transfected with indicated siRNAs (\#1 and \#2 represent two different sequences) for $48 \mathrm{~h}$, treated with or without $20 \mathrm{mmol} / \mathrm{L}$ Metformin for another $12 \mathrm{~h}$. Cell lysates were immunoblotted with indicated antibodies. (E) HEK293T cells were transfected with Hsc70-Flag for $24 \mathrm{~h}$, treated with or without $20 \mathrm{mmol} / \mathrm{L}$ Metformin for another $6 \mathrm{~h}$, the interaction between HK2, PKM2, and Hsc70 were analyzed by immunoprecipitation. (F) HEK293T cells were transfected with Lamp2a-Flag for $24 \mathrm{~h}$, treated with or without 20 $\mathrm{mmol} / \mathrm{L}$ Metformin for another $6 \mathrm{~h}$, the interaction between HK2, PKM2, and Lamp2a were analyzed by immunoprecipitation. (G) $\mathrm{H} 4$ cells were treated with or without $20 \mathrm{mmol} / \mathrm{L}$ Metformin for $6 \mathrm{~h}, \mathrm{PLA}$ assay for endogenous Hsc70 and PKM2 was analyzed by fluorescence microscopy. Scale bar, $100 \mu \mathrm{m}$. (H) Quantification of the fluorescence intensity of Texas Red from (G) (data represents mean $\pm \mathrm{SD}$; ${ }^{* * * *} P<0.0001$, one-way ANOVA). (I) H4 cells were treated with or without $20 \mathrm{mmol} / \mathrm{L}$ Metformin for $6 \mathrm{~h}, \mathrm{PLA}$ assay for endogenous Lamp2a and PKM2 was analyzed by fluorescence microscopy. Scale bar, $100 \mu \mathrm{m}$. (J) Quantification of the fluorescence intensity of Texas Red from (I) (data represents mean $\pm S D$; ${ }^{* * * \star} P<0.0001$, one-way ANOVA).

\section{OPEN ACCESS}

This article is licensed under a Creative Commons Attribution 4.0 International License, which permits use, sharing, adaptation, distribution and reproduction in any medium or format, as long as you give appropriate credit to the original author(s) and the source, provide a link to the Creative Commons licence, and indicate if changes were made. The images or other third party material in this article are included in the article's Creative Commons licence, unless indicated otherwise in a credit line to the material. If material is not included in the article's Creative Commons licence and your intended use is not permitted by statutory regulation or exceeds the permitted use, you will need to obtain permission directly from the copyright holder. To view a copy of this licence, visit http:// creativecommons.org/licenses/by/4.0/. 